Torday writes with great clarity and economy, while often hitting high emotional notes. He also has a real ear for dialogue and conveys the essence of his characters through speech rather than description. The county set who hover around Francis Black's wonderful wine collection, and Wilberforce's business partner, Andy, are beautifully drawn, largely through their conversations. Because the writing is so good and clear, the distinctions between fantasy, encephalopathy and psychopathology are often difficult to catch. The sense of unreality is heightened by the recurrent, and slightly over-worked, intrusion of a bad dream set in Bogota, while Wilberforce's unshakable loyalty to Francis and his clarets, against all odds, is itself testimony to the power of dreams and illusions. Some of the most shocking and inappropriate events are described in a chillingly clinical way, reminiscent of Elizabeth Highsmith's descriptions of Tom Ripley's antics.

This book will probably be described as a good summer read (especially for holidays in the south of France) but it is more than that, and I'm looking forward to hearing more from Paul Torday.

\section{Roger Jones}

DOI: 10.3399/bjgp09X471738

\title{
Epidemics of epidemics
}

\section{DREAD: HOW FEAR AND \\ FANTASY HAVE FUELED \\ EPIDEMICS FROM THE \\ BLACK DEATH TO AVIAN FLU \\ PHILIP ALCABES \\ Public Affairs, US, 2009 \\ pp336, \$26.95, 9781586486181}

As we tremble in anticipation of the predicted second wave of the great swine flu pandemic, Philip Alcabes tells us that can be confident of one thing. Contrary to the apocalyptic hype, history - in the form of the 1918 Spanish Flu pandemic that killed 50 million, perhaps 70 million, people worldwide - will not repeat itself. Although it was written before the emergence of swine flu from Mexico earlier this year, Alcabes' thoughtful historical study of epidemics provides valuable insights into our current predicament.

'The great calamities', writes Alcabes, 'are always, and have always been, unforeseeable and unimaginable until the moment they begin'. He argues persuasively that it is a waste of time and energy to prepare for what we can't foresee and 'a lie to pretend that we can see what we cannot'. While it makes sense to prepare for probable dangers (snow in winter and drought in summer) and to plan for present dangers (such as malaria in Africa and MRSA in hospitals), 'there's nothing to be gained by trying to prepare for the unlikely and unforseeable'.

Alcabes depicts today's health officials as 'soothsayers' and public health policy as 'a magic show'. Whereas in the past authorities recommended protective measures against outbreaks of infectious diseases, now they identify imaginary dangers (such as bioterrorism) and prescribe preventive measures, which do nothing to make us safer (but legitimate the authorities, even if the threat fails to materialise). Politicians and scientists keep identifying new epidemics (of social problems such as binge drinking and internet stalking, as well as of viral infections). Their incessant exhortations to be aware and vigilant and to curb risky behaviours are amplified by the media, fostering public anxieties. The result is a climate responsive to the promotion of 'a new brand of piety, in which everyone is supposed to worship at the altar of "healthy lifestyle choices"'.

For Alcabes, the archetypal postmodern epidemics of obesity and autism 'signal new failures' and reveal deep anxieties in contemporary society. In common with other critics of the popular notion that there has been a recent dramatic increase in the prevalence of these conditions, Alcabes notes the manipulation of statistics and blurring of diagnostic categories and boundaries. He argues that the increased recognition of both obesity and autism reflects widespread concerns about personal and social behaviour, individual and communal failure, fears about childhood and parenting, performance at school and work, and anxieties about the future health of individuals and society:

'Overweight adults and children whose behaviour is unusual suddenly become exemplars of the threat of modern life, unprecedented and uniquely dangerous.'

The result of the current epidemic of epidemics is a 'perfectly vicious circle'. Fears of modernity are expressed in a sense of heightened vulnerability to epidemics 'whose imaginary germs lurk in our character, our modern psyche, or our technology'. Diagnosis acts as a pointer towards a growing range of therapeutic interventions, encouraging the widening application of the diagnostic label, and, in turn, boosting the prevalence of the condition and confirming the concept of an epidemic. One consequence of this process is that it "leaves us open to manipulation by people who seek support for their political agendas or moral campaigns'. 'By declaring a problem to be epidemic, the powerful assert a right to manage it, and in managing it, they tell us how we should act.'

'Nature', notes Alcabes in his epilogue, 'has always outdone our worst fears'. And humans have yet to outdo Nature in destructive power: the Asian Tsunami in December 2004 killed 100 times as many people as died in the attack on the World Trade Centre on 11 September 2001. Real catastrophes are never as we imagine them - but when they happen people deal with them, as they did in Asia and in the US. In the meantime, we should set aside pandemic scaremongering and let people get on with their lives and doctors with their work.

DOI: 10.3399/bigp09X471747 